\title{
PENGARUH STORE ATMOSPHERE, KUALITAS PELAYANAN, DAN KEBERAGAMAN PRODUK TERHADAP MINAT BELI KONSUMEN (Studi Kasus Minimarket Koperasi Karyawan Pura Group Kudus)
}

\author{
Agung Fajar Ramadhan \\ Suhadi \\ Jurusan Syariah dan Ekonomi Islam STAIN Kudus \\ Salwalubna44@gmail.com
}

\begin{abstract}
Abstact
This study aims to determine the effect of Store Atmosphere, service quality, and product diversity on consumer buying interest. This research was conducted at Minimarket Koperasi Karyawan Pura Group. Population in this research is all cash consumer of Minimarket Koperasi Karyawan Pura Group. The sample used amounted to 40 respondents. Data collection techniques used were observation, questionnaire, and documentation. Data analysis in this study using the help of SPSS. Data testing techniques used in this study include the validity test, reliability test, classical assumption test, and multiple linear regression analysis to test and prove the research hypothesis. From the results of this study indicate that Store Atmosphere positively and significantly influence on consumer buying interest in Minimarket Koperasi Karyawan Pura Group. This is evidenced by the regression coefficient of 0.367 and the significance value of 0.001 (sig <0.05). While the calculated value obtained is greater than the table that is 3.675> 2.028. Quality of service influence positively and significantly to consumer buying interest in Minimarket Koperasi Karyawan Pura Group. This is evidenced by a regression coefficient of 0.348 and a significance value of 0.000 ( $\mathrm{sig}<0.05$ ). While the calculated value obtained is greater than the table that is 4.274> 2.028. The diversity of products has a positive and significant effect on consumer buying interest in Minimarket Koperasi
\end{abstract}


Karyawan Pura Group. This is evidenced by the regression coefficient of 0.265 and a significance value of 0.042 ( $\mathrm{sig}<0.05$ ). While the calculated value obtained is greater than the table that is 2.107> 2.028. Based on the determination coefficient test obtained by the percentage influence of Store Atmosphere variables, service quality, and product diversity toward consumer buying interest by $69.9 \%$.

Keywords: Store Atmosphere, Quality of Service, Product Diversity, Buy Interest

\section{A. Pendahuluan}

Perkembangan ritel di Indonesia berjalan seiring dengan dinamika dan dasar permintaan serta Kebutuhan konsumen. Interaksi konsumen sebagai anggota masyarakat lambat laun mempengaruhi konstelasi persaingan ritel dikemudian hari. Ritel modern seperti Supermarket, Hipermarket, dan Minimarket kian menjamur di kota-kota besar. Konsep ritel sekarang terfokus pada gerai area penjualan yang besar dan tempat parkir yang luas dengan berbagai fasilitas kemudahan dan kenyamanan sehingga membuat pengunjung tetap betah berlama-lama di dalam toko. Ritel modern biasanya memiliki lebih dari 20 kasir dan menjual tak kurang dari 25.000 Item barang. Format bisnis ritel lainnya rata-rata memiliki luas gerai bervariasi, mulai dari $600 \mathrm{~m}^{2}$ hingga $40.000 \mathrm{~m}^{2}$ dengan berbagai kelengkapan sarana penunjang seperti Eskalator, Lift, Ruangan ber AC, tempat arena bermain anak-anak, dan berbagai macam fasilitas lainnya (Lili Karmela F dan Jujun Junaedi , 2009: 94).

Menurut Erwin Rediono Tan (2011: 25) bahwa eksistensi ritel saat ini tidak bisa dilepaskan dari kebutuhan masyarakat yang semakin berkembang dan juga mengalami perubahan. Ritel yang ada jelas akan berusaha memenuhi dan menyediakan berbagai kebutuhan yang diperlukan konsumen. Salah satunya yang dapat diberikan atau dipenuhi oleh pihak peritel kepada konsumen, yaitu dengan menciptakan suasana toko yang nyaman, fasilitas yang memadai, memberikan pelayanan yang baik kepada konsumen, serta barang atau jasa yang mempunyai nilai lebih dari para kompetitornya. 
Strategi pemasaran yang berorientasi pada konsumen lebih banyak digunakan oleh para pelaku bisnis, meskipun hal ini mengharuskan para pelaku bisnis tersebut untuk mendefinisikan "want and need" dari sudut pandang konsumen. Pasar yang semakin dinamis, mengharuskan para pelaku bisnis untuk secara terus menerus berimprovisasi dan berinovasi dalam mempertahankan konsumennya (Resti Meldarianda, Hengky Lisan S, 2010: 97).

Persaingan kompetitif antar bisnis ritel modern, menyebabkan diperlukannya peningkatan kekuatan dalam perusahaan agar mampu menarik minat beli konsumen yang dapat dilakukan dengan cara memunculkan keunikan atau suatu ciri khas sebuah toko atau perusahaan yang membedakan dengan para pesaingnya. Salah satu strategi pemasaran yang dapat dilakukan retailer adalah dengan cara menciptakan Store Atmosphere yang nyaman agar dapat memberi kesan yang menarik kepada konsumen sehingga menimbulkan minat yang dapat mempengaruhi konsumen melakukan pembelian. Store Atmosphere merupakan suatu keadaan atau suasana dari toko yang dimana secara tidak langsung dapat mempengaruhi minat beli dari seorang konsumen tersebut. Dengan kata lain, Store Atmosphere bisa mempengaruhi perasaan atau mood dari para konsumen yang berkunjung ke toko sehingga mempengaruhi minat untuk malakukan pembelian (Ni Luh Julianti, Made Nuridja, Made Ary Meitriana, 2014).

Strategi keberagaman produk juga termasuk strategi yang juga perlu dirumuskan oleh retailer dalam menarik minat beli. Penting bagi retailer untuk menyediakan produk yang beranekaragam, hal ini dikarenakan adanya kecenderungan dalam diri konsumen yang menghendaki barang-barang yang beragam, sehingga dengan bermacam-macam produk yang disediakan diharapkan dapat memberikan dorongan dan pilihan bagi konsumen untuk membeli produk yang disediakan oleh retailer. Penyediaan keragaman produk (product assortment) yang baik tidak hanya akan menarik minat, tetapi dapat mempengaruhi keputusan konsumen untuk melakukan pembelian. Dengan demikian para konsumen tidak perlu memerlukan waktu dan tenaga untuk pergi ke retailer lain, 
untuk mencari produk yang tidak mereka dapatkan di retailer yang mereka kunjungi sebelumnya.

Berdasarkan penjelasan di atas dapat disimpulkan bahwa perusahaan ritel harus mampu menciptakan faktorfaktor yang dapat menumbuhkan minat beli dalam diri konsumen. Mengapa demikian, karena konsumen akan melihat dari berbagai faktor-faktor yang ada dalam menumbuhkan minat mereka untuk melakukan pembelian. Sebagai contoh faktor suasana toko yang nyaman, kualitas pelayanan yang diberikan minimarket sangat baik di mata konsumen, kemudian faktor yang lainnya adalah faktor keragaman produk yang ada di minimarket tersebut. Dengan mempertimbangkan faktor-faktor tersebut diharapkan perusahaan ritel dapat menumbuhkan minat beli konsumen dan berimbas pada meningkatnya volume penjualan.

Minimarket koperasi karyawan Pura Group merupakan sebuah usaha yang bergerak dibidang penjualan barang meliputi kebutuhan rumah tangga, alat-alat perkantoran, dan lain sebagainya. Minimarket tersebut merupakan salah satu unit usaha yang cukup besar yang dikelola oleh koperasi karyawan Pura Group. Sistim penjualan barang yang diterapkan minimarket tersebut bisa secara kredit maupun tunai. Penjualan secara kredit berlaku hanya untuk anggota koperasi, pembayarannya dengan cara pemotongan gaji setiap bulan dan dikenakan bunga sebesar 0,4\%. Sedangkan pembayaran secara tunai dapat dilakukan masyarakat umum. Tujuan utama dari pendirian usaha tersebut ialah untuk memenuhi tuntutan gaya hidup anggota koperasi maupun masyarakat dalam berbelanja yang saat ini serba modern, adapun tujuan lain ialah memberikan kemudahan bagi anggota koperasi maupun masyarakat untuk memperoleh barangbarang yang ditawarkan. Minimarket koperasi karyawan Pura Group memiliki jam buka toko mulai pukul 08.00 sampai 20.00 untuk hari senin sampai jum'at, dan pukul 08.00 sampai 17.00 untuk hari sabtu, sedangkan untuk hari minggu libur.8

Lokasi strategis minimarket koperasi karyawan Pura Group berada di Jalan Kresna Tanjung Karang, Jati Kudus. Lokasi tersebut merupakan lokasi yang sangat strategis karena berada di pinggir jalan raya yang sering dilalui oleh karyawan perusahaan swasta, mengingat lokasi tersebut memang dekat 
dengan perusahan besar seperti PT. Pura Barutama, PT. Djarum, dan PT. Nojorono. Selain dekat dengan perusahaan berskala besar lokasi tersebut juga dekat dengan pemukiman padat penduduk.

Berdasarkan penjelasan di atas, maka pertanyaan dalam penelitian ini adalah apakah Store Atmosphere, kualitas pelayanan, keberagaman produk berpengaruh terhadap minat beli konsumen di minimarket koperasi karyawan Pura Group Kudus.

Penelitian ini diharapkan akan bermanfaat bagi usaha usaha jasa sejenis khususnya bagi pemilik usaha jasa untuk dapat memberikan gambaran yang mendalam bagi mengenai faktor-faktor yang diidentifikasi mempengaruhi minat beli beserta hubungan antar variabel dalam penelitian ini, sehingga Minimarket Koperasi Karyawan Pura Group dapat mengambil keputusan dan menerapkan kebijakan yang tepat dalam rangka meningkatkan minat beli konsumen. Selain itu penelitian ini diharapkan dapat menambah khazanah ilmu pengetahuan dalam bidang manajemen pemasaran khususnya mengenai pengaruh Store Atmosphere, kualitas pelayanan, dan keberagaman produk terhadap minat beli konsumen dalam suatu perusahaan ritel.

\section{B. Pembahasan}

\section{Landasan Teori}

\section{a. Store Atmosphere (Suasana Toko)}

Store Atmosphere dapat digambarkan sebagai perubahan terhadap perancangan lingkungan pembelian yang menghasilkan efek emosional khusus yang dapat menyebabkan konsumen melakukan tindakan pembelian. Suatu toko harus membentuk suasana terencana yang sesuai dengan pasar sasarannya dan dapat menarik konsumen untuk membeli di toko tersebut. Sedangkan menurut Lamb, Hair, dan Mc Daniel dalam kutipan Lili Karmela dan Jujun Junaedi bahwa, suasana (atmosphere) merupakan kesan keseluruhan yang disampaikan oleh tata letak fisik toko, dekorasi, dan lingkungan sekitarnya (Lili Karmela F dan Jujun Junaedi, 2009: 95).

Atmosphere (suasana) mempengaruhi sejauh mana konsumen menghabiskan uang di luar tingkat yang direncanakan di sebuah toko. Store Atmosphere (suasana toko) 
mempengaruhi keadaan emosional pembelanja, yang kemudian mendorong untuk meningkatkan atau mengurangi belanja. Keadaan emosional terdiri dari dua perasaan yang dominan (kesenangan atau bergairah). Kombinasi unsur-unsur ini mempengaruhi konsumen untuk menghabiskan lebih sedikit atau lebih banyak waktu di toko.

\section{b. Penciptaan Store Atmosphere}

Menurut Lewinson dalam bukunya Bob Foster, (2008: 61-63), agar konsumen merasa senang berkunjung, maka pedagang eceran harus senantiasa mengusahakan suasana yang menyenangkan bagi para pengunjung, suasana tersebut dapat diciptakan melalui 3 hal, yaitu pertama, exterior. Exterior meliputi keseluruhan bangunan fisik yang dapat dilihat dari bentuk bangunan, pintu masuk, papan nama, dan lain-lain. Dalam retail, desain exterior merupakan bagian dari fasilitas fisik yang mempunyai peranan dalam memberi tempat bagi mereka yang akan datang. Kedua, interior. Desain interior yang dimiliki toko eceran pada dasarnya harus sesuai dengan desain eksteriornya. Hal ini sangat perlu demi menjaga keseimbangan citra yang telah terbentuk dari luar gedung. Beberapa komponen yang dapat didefinisikan untuk interior adalah estetika, perancangan ruang, dan tata letak (lay out) toko. Estetika toko menyangkut bagaimana fasilitas toko dapat menciptakan kesan yang mempengaruhi perasaan konsumen, yaitu pandangan dan perasaan konsumen mengenai suasana toko ketika melakukan kunjungan atau berbelanja di toko yang bersangkutan. Sedangkan perencanaan ruang, yaitu menyangkut bagaimana peritel memanfaatkan seluruh ruang yang ada sesuai dengan tingkat produksi pengecer itu sendiri. Perancangan ruang terdiri dari pemanfaatan ruang dan pengalokasian ruangan, bersama-sama dengan aspek penting di atas, penerapan dekorasi, serta kebersihan turut menunjang suasana berbelanja yang menyenangkan. Ketiga, tata letak (lay out). Tata letak toko merupakan pengaturan secara fisik mengenai, penempatan barang dagangan, perlengkapan tetap, dan departemen di dalam toko. Tujuan dari tata letak toko adalah memberikan gerak pada konsumen, memperlihatkan barang dagangan atau jasa, serta menarik dan memaksimalkan penjualan secara umum. 


\section{c. Kualitas Pelayanan}

Dalam rangka menciptakan minat beli pelanggan, pelayanan yang ditawarkan oleh perusahaan harus berkualitas. Istilah kualitas sendiri mengandung berbagai macam penafsiran, karena kualitas memiliki sejumlah level diantaranya, universal (sama dimanapun), cultural (tergantung sistim nilai budaya), sosial (dibentuk oleh kelas social ekonomi, kelompok etnis, keluarga, teman sepergaulan), dan personal (tergantung preferensi atau selera setiap individu). Secara sederhana, kualitas dapat diartikan "fitness for use" dan "conformance to requirements"( Fandy Tjiptono, dkk, 2008: 67). Kualitas mencerminkan semua dimensi penawaran pelayanan yang menghasilkan manfaat (benefits) bagi pelanggan.

Ratminto dan Atik Septi Winarsih, (2007: 2) berpendapat pelayanan merupakan suatu aktivitas atau serangkaian aktivitas yang bersifat tidak kasat mata (tidak dapat diraba) yang terjadi sebagai akibat adanya interaksi antara konsumen dengan karyawan atau hal-hal lain yang disediakan oleh perusahaan pemberi pelayanan yang dimaksudkan untuk memecahkan permasalahan konsumen atau pelanggan.

\section{d. Komponen Kualitas Pelayanan}

Komponen kualitas pelayanan total terdiri dari tiga hal yaitu, pertama kualitas teknik. Merupakan komponen yang berkaitan dengan kualitas output jasa yang diterima pelanggan. Kualitas teknik dapat diperinci lagi menjadi. Kedua, kualitas fungsional Merupakan komponen yang berkaitan dengan kualitas cara penyampaian jasa. Dan ketiga, citra korporat. Merupakan profil, reputasi, citra umum dan daya tarik perusahaan. (A. Usmara, 2003: 230).

\section{e. Keberagaman Produk}

Produk dibeli oleh konsumen karena dapat memenuhi kebutuhan tertentu atau memberi manfaat tertentu. Produk adalah segala sesuatu yang dapat ditawarkan ke suatu pasar untuk memenuhi kebutuhan atau keinginan (Philip Kotler, 2002: 448). Produk merupakan sesuatu yang kompleks baik dapat diraba maupun tidak dapat diraba termasuk bungkus, 
warna, harga prestise perusahaan dan pengecer, pelayanan perusahaan dan pengecer yang diterima oleh konsumen untuk memuaskan keinginan atau kebutuhannya (Hendra Fure, 2013, 274).

Philip Kotler, (2002: 453) mengemukakan bahwa product assortment (bauran produk) merupakan kumpulan dari semua produk dan unit produk yang ditawarkan penjual tertentu kepada pembeli. Dari pengertian tersebut, dapat disimpulkan bahwa keragaman produk merupakan ketersediaan serta kelengkapan berbagai macam jenis produk di suatu toko yang dapat memenuhi kebutuhan konsumen.

Salah satu kunci keberhasilan bisnis eceran dengan para pesaingnya adalah ragam produk yang disediakan oleh pengecer. Oleh karena itu, pengecer harus mampu menyediakan ragam produk yang memang benar- benar sesuai kebutuhan target marketnya (Sopiah, Syihabudhin, 2008: 84).

\section{f. Klasifikasi Produk}

Karakteristik produk tidak hanya meliputi aspek fisik produk (tangible features), tetapi juga aspek non fisik (intangible features) seperti citra dan jasa yang dapat dilihat. Dalam hal ini keberagaman produk dapat dilihat dari kategori produk yang tersedia disuatu perusahaan retail, dimana pemasar membagi produk berdasarkan proses pembelian dan penggunaannya menjadi produk konsumsi (Consumption Product) dan produk industry (Tri Widodo, 2016,: 101).

\section{g. Minat Beli}

Secara sederhana minat dapat diartikan sebagai suatu kecenderungan untuk memberikan perhatian dan bertindak terhadap orang, aktivitas atau situasi yang menjadi objek dari minat tersebut dengan disertai perasaan senang (Abdul Rahman Shaleh, 2004: 262-263).

Dalam batasan tersebut terkandung suatu pengertian bahwa di dalam minat ada pemusatan perhatian subjek, ada usaha untuk mendekati, mengetahui, memiliki, menguasai berhubungan dari subjek yang dilakukan dengan perasaan senang, ada daya penarik dari objek. 


\section{h. Faktor-faktor yang Mempengaruhi Timbulnya Minat}

Menurut Crow and Crow dalam bukunya Abdul Rahman Shaleh berpendapat bahwa ada tiga faktor yang mempengaruhi timbulnya minat. Pertama, dorongan dari dalam diri individu, misal dorongan untuk makan. Kedua, motif sosial, dapat menjadi faktor yang membangkitkan minat untuk melakukan suatu aktivitas tertentu. Misalnya minat terhadap pakaian timbul karena ingin mendapat persetujuan atau penerimaan dan perhatian orang lain. Ketiga, faktor emosional, minat mempunyai hubungan erat dengan emosi. Bila seseorang mendapatkan kesuksesan pada aktivitas akan menimbulkan perasaan senang, dan hal tersebut akan memperkuat minat terhadap aktivitas tersebut, sebaliknya suatu kegagalan akan menghilangkan minat terhadap hal tersebut (Abdul Rahman Shaleh, 2004: 264-265).

\section{i. Aspek-aspek Minat Beli}

Lucas dan Brit dalam kutipan Chandra Dewi dan Nuryati, menjelaskan bahwa aspek-aspek yang terdapat dalam minat beli antara lain (Chandra Dewi dan Nuryati, 2014: 56).

a. Perhatian Adanya perhatian yang besar dari konsumen terhadap suatu produk (barang atau jasa)

b. Ketertarikan

Setelah adanya perhatian maka akan timbul rasa tertarik pada konsumen

c. Keinginan

Berlanjut pada perasaan untuk mengingini atau memiliki suatu produk tersebut

d. Keyakinan

Kemudian timbul keyakinan pada diri individu terhadap produk tersebut sehingga menimbulkan keputusan (proses akhir) untuk memperolehnya dengan tindakan yang disebut membeli.

e. Keputusan

Dari lima aspek tersebut dapat disimpulkan menjadi tiga aspek dalam minat beli antara lain:

1) Ketertarikan (interest)

Yang menunjukkan adanya pemusatan perhatian dan perasaan senang

2) Keinginan (desire) 
Ditunjukkan dengan adanya dorongan untuk memiliki

3) Keyakinan (Convicition)

Ditunjukkan dengan adanya perasaan percaya diri individu terhadap kualitas, daya guna dan keuntungan dari produk yang akan dibeli. Aspek perhatian tidak digunakan karena masih berupa perhatian belum bisa dikatakan sebagai minat, karena tidak adanya dorongan untuk memiliki.

2. Model Kerangka Pemikiran Teoristis Variabel Independen Variabel Dependen

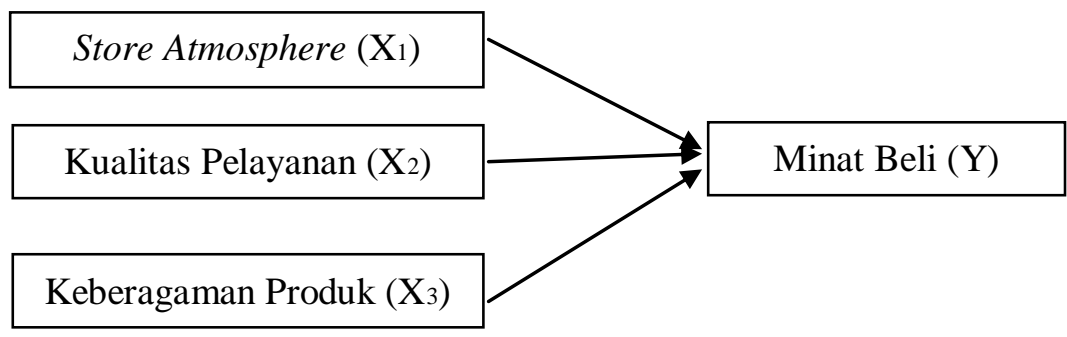

\section{Hipotesis}

Berdasarkan berbagai penelitian diatas, maka penelitian ini menguji empat hipotesis sebagai berikut:

$\mathrm{H}_{1}$ : Store Atmosphere berpengaruh secara positif dan signifikan terhadap minat beli konsumen Minimarket Koperasi Karyawan Pura Group.

$\mathrm{H} 2$ : Kualitas pelayanan berpengaruh secara positif dan signifikan terhadap minat beli konsumen Minimarket Koperasi Karyawan Pura Group.

H3 : Keberagaman produk berpengaruh secara positif dan signifikan terhadap minat beli konsumen Minimarket Koperasi Karyawan Pura Group.

\section{Metode Penelitian}

Populasi dalam penelitian ini adalah seluruh konsumen yang melakukan pembelian secara tunai di Minimarket Koperasi Karyawan Pura Group. Pengambilan sampel dalam 
penelitian ini menggunakan metode non probability sampling, dengan menggunakan tekhnik insidental, yaitu teknik penentuan sampel berdasarkan kebetulan.

Variabel independen dalam penelitian ini adalah Store Atmosphere $\left(\mathrm{X}_{1}\right)$, kualitas pelayanan $\left(\mathrm{X}_{2}\right)$, dan keberagaman produk $\left(X_{3}\right)$. Sedangkan yang menjadi variabel dependen adalah minat beli $(Y)$. Tehnik pengumpulan data menggunakan wawancara dan questioner. Pengolahan data menggunakan coding, editing dan tabulating, sedangkan analisis menggunakan regresi dengan uji t.

\section{Pembahasan}

\section{Analisis Regresi Berganda}

Analisis regresi berganda dalam penelitian ini bertujuan untuk mengetahui besarnya pengaruh variabel independen Store Atmosphere $\left(\mathrm{X}_{1}\right)$, kualitas pelayanan $\left(\mathrm{X}_{2}\right)$, dan keberagaman produk $\left(X_{3}\right)$ terhadap variabel dependen, yaitu minat beli $(Y)$. Ringkasan hasil pengolahan data dengan menggunakan program SPSS tersebut adalah sebagai berikut :

\section{Hasil Analisis Regresi}

\begin{tabular}{|l|c|c|c|}
\hline \multicolumn{1}{|c|}{ Keterangan } & $\begin{array}{c}\text { Nilai } \\
\text { Koefisien }\end{array}$ & $\begin{array}{c}\text { Nilai t } \\
\text { Hitung }\end{array}$ & $\begin{array}{c}\text { Nilai } \\
\text { Signifikan }\end{array}$ \\
\hline Store Atmosphere & 0,367 & 3,675 & 0,001 \\
Kualitas Pelayanan & 0,348 & 4,274 & 0,000 \\
Keberagaman & 0,265 & 2,107 & 0,042 \\
Produk & \multicolumn{3}{|c|}{3,178} \\
\hline Nilai Konstanta & 2,028 \\
Nilai t Tabel & \multicolumn{3}{|c}{$099(69,9 \%)$} \\
R Square & \multicolumn{3}{|c|}{} \\
\hline
\end{tabular}

Hasil analisis regresi berganda dapat dilihat pada tabel di atas, dari tabel tersebut diperoleh koefisien untuk variabel bebas $X_{1}=0,367, X_{2}=0,348$, dan $X_{3}=0,265$ sedangkan konstanta sebesar 3,178 sehingga model persamaan regresi yang diperoleh ialah:

$$
\begin{aligned}
& Y=a+b_{1} X_{1}+b_{2} X_{2}+b_{3} X_{2}+e \\
& Y=3,178+0,367 X_{1}+0,348 \times 2+0,265 X_{3}+e
\end{aligned}
$$

Persamaan regresi linier berganda tersebut dapat diartikan bahwa: 
a. Konstanta sebesar 3,178, artinya jika Store Atmosphere $\left(\mathrm{X}_{1}\right)$, kualitas pelayanan $\left(\mathrm{X}_{2}\right)$, dan keberagaman produk $\left(\mathrm{X}_{3}\right)$ nilainya dianggap konstan (0), maka variabel minat beli $(\mathrm{Y})$ memiliki nilai 3,178.

b. Koefisien regresi Store Atmosphere $\left(\mathrm{X}_{1}\right)$ dari perhitungan linier berganda didapat nilai coefficient $\left(b_{1}\right)=0,367$. Hal ini menyatakan bahwa setiap kenaikan Store Atmosphere $\left(\mathrm{X}_{1}\right)$ sebesar 1\% akan meningkatkan minat beli konsumen Minimarket Koperasi Karyawan Pura Group (Y) sebesar 0,367 dengan anggapan variabel kualitas pelayanan $\left(X_{2}\right)$ dan keberagaman produk $\left(X_{3}\right)$ bernilai konstan.

c. Koefisien regresi kualitas pelayanan $\left(\mathrm{X}_{2}\right)$ dari perhitungan linier berganda didapat nilai coefficient $\left(\mathrm{b}_{2}\right)=0,348$. Hal ini menyatakan bahwa setiap kenaikan kualitas pelayanan $\left(\mathrm{X}_{2}\right)$ sebesar 1\% akan meningkatkan minat beli konsumen Minimarket Koperasi Karyawan Pura Group (Y) sebesar 0,348 dengan anggapan variabel Store Atmosphere $\left(X_{1}\right)$ dan keberagaman produk $\left(X_{3}\right)$ bernilai konstan.

d.Koefisien regresi keberagaman produk $\left(X_{3}\right)$ dari perhitungan linier berganda didapat nilai coefficient $\left(b_{3}\right)=0,265$. Hal ini menyatakan bahwa setiap kenaikan keberagaman produk $\left(\mathrm{X}_{3}\right)$ sebesar 1\% akan meningkatkan minat beli konsumen Minimarket Koperasi Karyawan Pura Group (Y) sebesar 0,265 dengan anggapan variabel Store Atmosphere $\left(X_{1}\right)$ dan kualitas pelayanan $\left(\mathrm{X}_{2}\right)$ bernilai konstan.

\section{Uji Signifikansi Parameter Individual (Uji t)}

Uji signifikansi parameter parsial bertujuan untuk mengetahui seberapa jauh pengaruh satu variabel independen secara individual dalam menerangkan variasi variabel dependen. Hasil uji t dengan penjelasan sebagai berikut:

a. Store Atmosphere (Suasana Toko)

Store Atmosphere memiliki tingkat signifikansi sebesar 0,001. Dari hasil uji $\mathrm{t}$ pada variabel Store Atmosphere menyatakan bahwa signifikansi uji $t$ lebih kecil dari 0,05 dan koefisien regresi mempunyai nilai positif sebesar 0,367. Sedangkan nilai $\mathrm{t}$ hitung yang diperoleh, yaitu 3,675 lebih besar dari nilai $t$ tabel 2,028. Berdasarkan hasil tersebut maka hipotesis yang menyatakan "Store Atmosphere berpengaruh 
secara positif dan signifikan terhadap minat beli konsumen minimarket koperasi karyawan Pura Group"diterima.

b. Kualitas Pelayanan

Kualitas pelayanan memiliki tingkat signifikansi sebesar 0,000. Dari hasil uji $\mathrm{t}$ pada variabel kualitas pelayanan menyatakan bahwa signifikansi uji t lebih kecil dari 0,05 dan koefisien regresi mempunyai nilai positif sebesar 0,348. Sedangkan nilai $\mathrm{t}$ hitung yang diperoleh, yaitu 4,274 lebih besar dari nilai $\mathrm{t}$ tabel 2,028. Berdasarkan hasil tersebut maka hipotesis yang menyatakan" kualitas pelayanan berpengaruh secara positif dan signifikan terhadap minat beli konsumen minimarket koperasi karyawan Pura Group" diterima.

\section{c. Keberagaman Produk}

Keberagaman produk memiliki tingkat signifikansi sebesar 0,042. Dari hasil uji $t$ pada variabel keberagaman produk menyatakan bahwa signifikansi uji t lebih kecil dari 0,05 dan koefisien regresi mempunyai nilai positif sebesar 0,265.

Sedangkan nilai $\mathrm{t}$ hitung yang diperoleh, yaitu 2,107 lebih besar dari nilai tabel 2,028. Berdasarkan hasil tersebut maka hipotesis yang menyatakan "keberagaman produk berpengaruh secara positif dan signifikan terhadap minat beli konsumen minimarket koperasi karyawan Pura Group" diterima.

\section{Koefisien Determinasi $\left(\mathrm{R}^{2}\right)$}

Koefisien determinasi (Adjusted $\mathrm{R}^{2}$ ) digunakan untuk mengukur besarnya sumbangan dari variabel bebas yang diteliti terhadap variasi variabel terikat. Dari tabel tersebut dapat diketahui bahwa nilai koefisien determinasi yang dinotasikan dalam angka $\mathrm{R}$ Square sebesar 0,699 ini artinya bahwa sumbangan pengaruh variabel Store Atmosphere $\left(\mathrm{X}_{1}\right)$, kualitas pelayanan $\left(X_{2}\right)$, dan keberagaman produk $\left(X_{3}\right)$ terhadap minat beli konsumen minimarket koperasi karyawan Pura Group (Y) sebesar 69,9\%. Jadi, besarnya pengaruh Store Atmosphere $\left(\mathrm{X}_{1}\right)$, kualitas pelayanan $\left(\mathrm{X}_{2}\right)$, dan keberagaman produk $\left(X_{3}\right)$ terhadap minat beli konsumen minimarket koperasi karyawan Pura Group (Y) sebesar 69,9\%. Sedangkan sisanya $30,1 \%$ dipengaruhi oleh variabel-variabel lain di luar penelitian ini. 
Berdasarkan hasil pengujian secara statistik dapat terlihat dengan jelas bahwa secara parsial (individu) semua variabel bebas berpengaruh terhadap variabel terikat. Hasil tersebut sesuai dengan hipotesis yang diajukan. Penjelasan dari masing-masing pengaruh variabel ialah sebagai berikut:

1. Pengaruh Store Atmosphere terhadap Minat Beli Konsumen Minimarket Koperasi Karyawan Pura Group

Store Atmosphere (suasana toko) merupakan seluruh efek estetika dan emosional yang diciptakan melalui ciri ciri fisik dari toko, dimana semuanya berhubungan dengan panca indera (penglihatan) dari konsumen dan dapat mempengaruhi emosi konsumen untuk melakukan pembelian.

Dari hasil uji $\mathrm{t}$ pada variabel Store Atmosphere memiliki tingkat signifikansi sebesar 0,001 itu artinya lebih kecil dari 0,05 dan koefisien regresi mempunyai nilai positif sebesar 0,367. Sedangkan nilai $t$ hitung yang diperoleh, yaitu 3,675 lebih besar dari nilai ttabel 2,028. Berdasarkan hasil tersebut maka hipotesis yang menyatakan "Store Atmosphere berpengaruh secara positif dan signifikan terhadap minat beli konsumen minimarket koperasi karyawan Pura Group" diterima.

Berdasarkan hasil penelitian ini, diketahui adanya pengaruh Store Atmosphere terhadap minat beli konsumen di minimarket koperasi karyawan Pura Group. Pengaruh yang ditimbulkan bersifat positif dan signifikan itu artinya bahwa semakin baik atau semakin nyaman Store Atmosphere yang diciptakan minimarket koperasi karyawan Pura Group kepada konsumen, maka semakin besar minat konsumen untuk melakukan pembelian.

2. Pengaruh Kualitas Pelayanan terhadap Minat Beli Konsumen

Minimarket Koperasi Karyawan Pura Group

Kualitas pelayanan merupakan tingkat keunggulan yang diharapkan dan pengendalian atas tingkat keunggulan tersebut untuk memenuhi harapan pelanggan. Apabila jasa yang dirasakan sesuai dengan yang diharapkan, maka kualitas dinilai baik dan memuaskan dimata konsumen. 
Dari hasil uji $\mathrm{t}$ pada variabel kualitas pelayanan memiliki tingkat signifikansi sebesar 0,000 itu artinya lebih kecil dari 0,05 dan koefisien regresi mempunyai nilai positif sebesar 0,348. Sedangkan nilai thitung yang diperoleh yaitu 4,274 lebih besar dari nilai ttabel 2,028. Berdasarkan hasil tersebut maka hipotesis yang menyatakan "kualitas pelayanan berpengaruh secara positif dan signifikan terhadap minat beli konsumen minimarket koperasi karyawan Pura Group" diterima.

Berdasarkan hasil penelitian ini, diketahui adanya pengaruh kualitas pelayanan terhadap minat beli konsumen di Minimarket Koperasi Karyawan Pura Group. Pengaruh yang ditimbulkan bersifat positif dan signifikan itu artinya bahwa semakin baik kualitas pelayanan yang diberikan Minimarket minimarket koperasi karyawan Pura Group kepada konsumen, maka semakin besar minat konsumen untuk melakukan pembelian. Namun sebaliknya, jika Minimarket Koperasi Karyawan Pura Group tidak memperhatikan lagi aspek kualitas pelayanan maka minat beli konsumen di Minimarket Koperasi Karyawan Pura Group akan menurun.

3. Pengaruh Keberagaman Produk terhadap Minat Beli Konsumen

Minimarket Koperasi Karyawan Pura Group

Keberagaman produk merupakan ketersediaan serta kelengkapan berbagai macam jenis produk di suatu toko yang dapat memenuhi kebutuhan konsumen. Salah satu kunci persaingan bisnis eceran adalah ragam produk yang disediakan oleh pengecer. Semakin banyak ragam produk pada suatu toko, maka semakin besar pula minat konsumen untuk melakukan pembelian pada toko tersebut. Selain itu juga, dengan beragamnya produk yang dijual akan memudahkan konsumen dalam memilih dan membeli berbagai macam produk sesuai dengan keinginan dan kebutuhan mereka.

Dari hasil uji $\mathrm{t}$ pada variabel keberagaman produk memiliki tingkat signifikansi sebesar 0,042 itu artinya lebih kecil dari 0,05 dan koefisien regresi mempunyai nilai positif sebesar 0,265 . Sedangkan nilai $t$ hitung yang diperoleh, 
yaitu 2,107 lebih besar dari nilai $t$ tabel 2,028. Berdasarkan hasil tersebut maka hipotesis yang menyatakan "keberagaman produk berpengaruh secara positif dan signifikan terhadap minat beli konsumen minimarket koperasi karyawan Pura Group" diterima.

Berdasarkan hasil penelitian ini, diketahui adanya pengaruh keberagaman produk terhadap minat beli konsumen di minimarket koperasi karyawan Pura Group. Pengaruh yang ditimbulkan bersifat positif dan signifikan itu artinya bahwa semakin beragam produk yang ditawarkan di minimarket koperasi karyawan Pura Group kepada konsumen, maka semakin besar minat konsumen untuk melakukan pembelian.

\section{E. Simpulan}

Dari hasil penelitian adalah terdapat beberapa kesimpulan yaitu :

1. Store Atmosphere (suasana toko) berpengaruh secara positif dan signifikan terhadap minat beli konsumen Minimarket Koperasi Karyawan Pura Group. Jika Minimarket Koperasi Karyawan Pura Group menginginkan minat beli konsumen meningkat, maka minimarket tersebut harus menciptakan Store Atmosphere yang nyaman dan menyenangkan kepada konsumen, karena dengan hal tersebut dapat membuat konsumen betah berlama-lama di minimarket dan berimbas pada bertambahnya pembelian.

2. Kualitas pelayanan berpengaruh secara positif dan signifikan terhadap minat beli konsumen Minimarket Koperasi Karyawan Pura Group. Jika Minimarket Koperasi Karyawan Pura Group menginginkan minat beli konsumen meningkat, maka minimarket tersebut harus memberikan pelayanan yang berkualitas kepada konsumen, karena dengan pelayanan yang berkualitas dapat memunculkan gairah konsumen untuk melakukan pembelian.

3. Keberagaman produk berpengaruh secara positif dan signifikan terhadap minat beli konsumen Minimarket Koperasi Karyawan Pura Group. Jika Minimarket Koperasi Karyawan Pura Group menginginkan minat beli konsumen meningkat, maka minimarket tersebut harus 
menyediakan beragam produk yang dibutuhkan oleh konsumen, dengan beragamnya produk yang tersedia maka konsumen tidak akan pergi ke toko lain untuk mendapatkan produk yang dicari. 
Pengaruh Store Atmosphere, Kualitas Pelayanan ...

\section{Daftar Pustaka}

A. Usmara. 2003. Strategi Baru Manajemen Pemasaran. Amara Books. Yogyakarta. hlm. 230.

Abdul Rahman Shaleh. 2004. Psikologi Suatu Pengantar Dalam Perspektif Islam. Prenada Media. Jakarta. hlm. 262-263.

Abdul Rahman Shaleh. Psikologi Suatu Pengantar Dalam Perspektif Islam. Prenada Media. Jakarta. 2004. hlm. 264265.

Bob Foster. 2008. Manajemen Ritel. Alfabeta. Bandung. hlm. 61.

Chandra Dewi dan Nuryati. 2014. Pengaruh Kualitas Pelayanan Terhadap Kepuasan dan Minat Beli Konsumen dirumah Makan Boga-Bogi Surakarta. Informatika. Vol. 1 No. 2. hlm. 56.

Erwin Rediono Tan. 2011. Pengaruh Faktor Harga, Promosi, dan Pelayanan Terhadap Keputusan Konsumen untuk Berbelanja di Alfamart Surabaya. Jurnal Kewirausahaan Vol. 5 No. 2. hlm. 25.

Fandy Tjiptono, dkk. 2008. Pemasaran Strategi. CV Andi Offset. Yogyakarta.hlm. 67.

Hendra Fure. 2013. Lokasi, Keberagaman Produk, Harga, dan Kualitas Pelayanan Pengaruhnya terhadap Minat Beli pada Pasar Tradisional Bersehati Calaca. Jurnal Emba Vol.1 No. 3. hlm. 274.

Lili Karmela F, Jujun Junaedi. 2009. Pengaruh Store Atmosphere Terhadap Minat Beli Konsumen Pada Toserba Griya Kuningan. Equilibrium Vol. 5 No. 9. hlm. 94.

Lili Karmela F, Jujun Junaedi. 2009. Pengaruh Store Atmosphere Terhadap Minat Beli Konsumen Pada Toserba Griya Kuningan. Equilibrium Vol. 5 No. 9. hlm. 95. 
Ni Luh Julianti, Made Nuridja, Made Ary Meitriana. 2014. Pengaruh Suasana Toko Terhadap Minat Beli Konsumen Pada Toserba Nusa Permai di Kecamatan Nusa Penida Bali. Universitas Pendidikan Ganesa Fakultas Ekonomi dan Bisnis Vol. 4 No. 1.

Philip Kotler. 2002. Manajemen Pemasaran, PT. Prenhallindo. Jakarta. hlm. 453

Ratminto dan Atik Septi Winarsih. 2007. Manajemen Pelayanan. Pustaka Pelajar. Yogyakarta. hlm. 2.

Resti Meldarianda, Hengky Lisan S. 2010. Pengaruh Store Atmosphere Terhadap Minat Beli Konsumen Pada Resort Café Atmosphere Bandung, Jurnal Bisnis dan Ekonomi (JBE) Vol. 17 No. 2. hlm. 97.

Sopiah, Syihabudhin. 2008. Manajemen Ritel Modern. CV Andi Offset. Yogyakarta. hlm. 84.

Tri Widodo. 2016. Pengaruh Kelengkapan Produk dan Kualitas Pelayanan terhadap Keputusan Pembelian. Among Markati Vol. 9 No. 17. hlm. 101. 